\title{
HOW HR PRACTICES AFFECT ORGANIZATIONAL COMMITMENT AND ORGANIZATIONAL CITIZENSHIP BEHAVIOR
}

\author{
Majida Jrad1
}

Received: 17.09.2020; Accepted: 01.10.2020

\begin{abstract}
The HRM and effective HR practices play an important role for promoting a committed environment and a culture of citizenship. This study is intended to explore the HRM systems' dynamics and applied HR practices in Lebanese banks and to find their possible link with employee commitment and citizenship behavior. The primary research selected six most representative Lebanese banks. A questionnaire on employee commitment and citizenship behavior was sent to each bank's HR officers. The questions were derived from the OCQ, ACS, CCS, NCS, and CBS. Direct positive relationship between HR and organizational commitment was not completely verified in terms of the Lebanese bank institutions. The HR-OCB relationship is much more coherent and noticeable especially when the HR role of employee champion emerges. Commitment has a strong relationship with the OCB. Lebanese banks have very promising examples of serious dynamic HRM initiatives that promote employees' support and recognize their efforts while trying to capitalize on their competences, commitment, and displayed citizenship behaviors.
\end{abstract}

Keywords: human resource management; commitment; questionnaire; Lebanese banks.

JEL Codes: C21; M51; M52; M54

\section{INTRODUCTION}

Human resource practices such as supportive environment, fairness and equality, employee participation and empowerment, extensive training, career development, and rewards were found to have significant positive impact on nurturing employee organizational commitment and citizenship behavior (Gaertner, 1999; Xiao and Björkman, 2006; Sun et al., 2007). Each organization should promote such effective HR systems that motivate and inspire employees

${ }^{1}$ Lorraine University, France. Researcher, e-mail: majida.jrad@hotmail.com ORCID ID: https://orcid.org/0000-0002-2849-9507 
who in turn will reciprocate this support with their individual commitment to the organization (Gould-Williams, 2004). By testing the validity of these correlations in the Lebanese framework, this study is intended to explore the HRM systems' dynamics and applied HR practices in Lebanese banks and to find their possible link with employee commitment and citizenship behavior. The hypothesis will be tested is the HR practices such as supportive environment, fairness and equality, and employee empowerment have significant positive effect on fostering employee organizational commitment and citizenship behavior in terms of Lebanon's banking sector.

The significance of this study lies in its attempt to establish a link between organizational parameters and employee attitudes in the Lebanese context. Moreover, the study will addresses the HR management in the Lebanon's banking sector that is among the best performing sectors of all the Lebanon's economy. The banking sector in Lebanon is one of the most profitable, highly liquid and well-capitalized in the region. For example, bank deposits exceeded USD 110 billion in 2010 that was among the best financial years for the banking sector of the country. In fact, Lebanon has attracted the largest share of bank deposits in the Middle East and North Africa region in the same year. Despite global credit tightening, credit to the private sector then reached the historical level of USD 36 billion, which is a growth rate of around $22 \%$, the highest in the region. Lebanese banks have a high level of liquidity and the structure and quality of their capital is generally in line with international regulatory standards on bank capital adequacy and liquidity, especially Basle III standards. Lebanese Banks have international presence. Thus along with working on the Lebanese market with 92 Banks covering the Lebanese territory, the Lebanese Banks have significant operations abroad, in countries such as Arab countries, southern and western European countries, African countries, USA, India, Japan, Australia and many other countries. Lebanese banks have branches, affiliated companies, subsidiaries, sister banks and representative offices spread in 25 countries around the world with more than 80 units. There is a very large network of correspondent banks.

The paper is structured in the following main sections. The next section reviews the empirical evidence on this topic to describe the place of present study in the entire evidence. Second section is devoted to the research methodology and its application to find relevant results. Third section presents the results of the application of the research methodology adopted and the discussion on these results. Last section concludes. 


\section{LITERATURE REVIEW}

Many studies have shown that HR practices can have a significant influence on firm performance (Huselid, 1995; Benkhoff, 1997; Collins and Clark, 2003; Sun et al., 2007). Human resource management has established notable value by helping companies locate and identify strengths and weaknesses in their resources and activities and which will ultimately have the highest impact on their performance. Managers would then be capable of fostering and benchmarking their firm's HRM competences and thus take action to enhance organizational policies, management approaches and HR practices. As pointed: "the overall purpose of human resource management is to ensure that the organization is able to achieve success through people" (Armstrong, 2006). In fact, HRM focuses the attention of the firm's management on the strategies and systems to be implemented in order to gain a higher added value from people achieving objectives in the following areas: organizational effectiveness, human capital management, knowledge management, reward management, employee and labor relations as well as meeting various needs (Armstrong, 2006; Mondy and Noe, 2005; Decenzo and Robbins, 2002).

Originally, literature relates $\mathrm{HR}$ to organizational performance. Clear positive relationship between HR practices and organizational performance was conceptualized two decades ago (Armstrong, 2006). Empirical studies provided evidence in favor of those conceptual predictions. Huselid (1995) directed an analysis of the responses of 968 US firms to a questionnaire investigating the use of high-performance work practices. These practices comprise meticulous recruitment and selection, intensive and appropriate training and management development activities, incentive paying, and performance management systems. The study also explored their synergies and their alignment with the corporate strategy and conclusively argued that workforce productivity is influenced by its motivation (Huselid, 1995) He also found that financial performance is affected by employee skills, motivation and organizational structures (Huselid, 1995; Sun et al., 2007).

Becker and Huselid (1998) adopted another approach. They established an index of HR systems in a sample of firms to specify the degree to which each firm took on a high-performance work system. The index comprised important dimensions, including HR strategy, employee motivation, selection and development, and compensation. They found 
that companies with superior values on the index had financially and statistically higher levels of performance and sustainable competitive advantage.

Becker et al. (1997) evaluated the outcomes of several research projects to gauge the strategic impact of high-performance HR systems on firm's shareholder value. They claimed that high performance systems will indeed have an impact as long as they are "rooted" in the management infrastructure. In their own words, HRM systems will only have a systematic effect on the bottom line when they are part of the managerial structure and help the company attain significant business priorities such as cutting product development cycle times, increasing customer service, reducing turnover among first-rate staff, etc.

High-performance HR practices have also been linked to organizational performance (productivity) through the mediating role of service-oriented citizenship behaviors (Sun et al., 2007). Actually, these practices promote employees' perception of supportive work setting and social climate (as trust and cooperation) that inspires discretionary behaviors, which in turn positively affect productivity and thus organizational performance. The stated voluntary behaviors have usually been conceptualized in terms of organizational citizenship behavior (OCB).

Guest et al. (2003) surveyed 366 private sector organizations in the UK and conducted interviews with $610 \mathrm{HR}$ professionals and 462 chief executives. The paper observed that a more systematic and greater use of HR practices (presented through 48 items) is linked to higher levels of labor productivity and higher profit per employee, thus reflecting greater profitability and superior financial performance. As well, employee perception of "developmental" HR practices (best methods) was found to increase the perceived quality of the employee-organization relationship (EOR) through four indicators: perceived organizational support, affective organizational commitment, and procedural and interactional justice. These EOR indicators, having a mediating function, would then enhance employees' work performance (Kuvaas, 2008).

Paul and Anantharaman (2003) observed that HRM practices such as training, job design, selection, compensation, incentives, and performance appraisal directly influence the operational performance parameters of the firm, for instance employee productivity, product quality, speed of delivery and operating cost. As well, each studied HRM 
practice had indirect impact on the financial performance of the organization. In an analogous paper by Wright et al. (2003), the researchers examined the impact of HR practices and organizational commitment on the operating performance and profitability of business units. Using a sample of 50 autonomous business units within the same company, the study demonstrates that both employee commitment and HR practices are (statistically) significantly linked to operational measures of performance like productivity and quality, as well as financial measures like operating expenses and pre-tax profits.

Likewise, financial performance was observed to be strongly linked to perceived HR practices and work climate at the business unit level. Inter-departmental cooperation and job security were found to be the most significant predictors (Van Veldhoven, 2005). On the other hand, Gilbreath and Montesino (2006) investigated Human Resource Development's (HRD) crucial role in evaluating and restructuring the work environment so as to promote dynamic, mentally focused workers that supply their organization with a competitive advantage. They conclude that HRD professionals, by emphasizing HRD's potential for organizational transformation, could in this way improve employees' quality of life and contribute to the firm's success.

Also, results from a survey conducted for CEOs of 73 high-tech firms revealed significant positive correlations between a set of networkbuilding HR practices (training, performance evaluation, rewards) and organizational performance. The relationships were mediated through the companies' top managers' social networks - the schemes of connections they have with internal and external players - whereas the most influenced performance indicators were sales growth and stock returns (Collins and Clark, 2003).

Human resource or more accurately human capital measurement has been defined as being "about finding links, correlations and, ideally, causation, between different sets of (HR) data, using statistical techniques". It actually handles "the analysis of the actual experience of employees, rather than stated HR programs and policies" (Armstrong, 2006).

Special attention is paid on the strategic approach in human resource management. An effective HR strategy realizes what it intended to realize (Mondy and Noe, 2005). Specifically, it will fulfill business needs, is established on thorough analysis and study, and may be developed into 
executable programs. Effectiveness also entails being logical and comprehensive as well as containing interconnected and consistent elements; it also involves catering for the needs of workers and managers in addition to all of the organization's stakeholders (Armstrong and Baron, 2002; Anthony et al., 2002; Mondy and Noe, 2005). The following is a comment from a chief executive on effective HR strategy: "is one which actually makes people feel valued. It makes them knowledgeable about the organization and makes them feel clear about where they sit as a group, or team, or individual" (Armstrong, 2006).

HRM has been evolving over recent years and it is now identified as an essential contributor to organizational effectiveness and strategic initiatives (Buck and Watson, 2002). Indeed, the strategic approach to HRM implies linking HRM with the firm's strategic objectives to enhance organizational performance (Decenzo and Robbins, 2002). Strategic HRM (SHRM) is actually concerned with strategic planning and decision making and coordinates all HR functions for all staff (Anthony et al., 2002).

Moreover, when a strategic decision has a major impacts on the firm's human capital, HR professionals have to advise and influence the decision process and thus become true business partners (Mondy and Noe, 2005). They should also acknowledge the contribution of HRM to the bottom line and promote the employees-employers communication (Becker and Huselid, 2006).

HRM seeks to enhance employees' job satisfaction and commitment to the organization by designing and crafting HRM strategies and practices that enhance motivation, participation, and full employee engagement. Commitment was found to be firmly linked to performance indicators such as productivity and profitability (Decenzo and Robbins, 2002; Wright et al., 2003). The focus of organizational commitment research evolved from employee behaviors to employee attitudes. Some studies put emphasis on the factors that are peculiar to the commitment (Porter et al., 1974; Mowday et al., 1979). Other economists consider the organizational commitment as a psychological phenomenon of linkage (Mellor et al., 2001; Schwepker, 2001; Moynihan and Pandey, 2008). There are "attitudinal" views for organizational commitment as well (Mowday et al., 1979; Salancik, 1977; Swailes, 2002; Buck and Watson, 2002).

Commitment is also viewed as a variable with three distinguishable components (rather than types) as per Meyer and Allen's three-component 
model: affective, continuance, and normative commitment (Meyer and Allen, 1991; Swailes, 2002; Buck and Watson, 2002). Continuance commitment defines the commitment originating from the perceived cost associated with leaving the organization, that is "having to stay" with the company (Meyer and Allen, 1997; Buck and Watson, 2002; Mellor et al., 2001). Normative commitment is used to describe an individual's feeling of obligation to remain with the organization, that is a "moral obligation to stay" with the firm (Meyer and Allen, 1997; Buck and Watson, 2002; Mellor et al., 2001; Swailes, 2002).

Several studies have verified that affective, continuance, and normative commitment are distinctive components of commitment. However, other research has reliably shown non-zero correlations between each of these. Most remarkably, the correlation between affective and normative commitment was regularly found to be fairly strong (Allen and Meyer, 1990; Meyer and Allen, 1991). Hence the three components should not be regarded as mutually exclusive commitment forms, but as elements that can commonly coexist; so an employee's commitment may be made of one, two, or all three constituents (Meyer and Allen, 1997). On the other hand, some researchers asserted that, in spite of their high correlation, affective and normative commitment display sufficiently various correlations with other variables, particularly variables supposed to be antecedents (Allen and Meyer, 1990) or outcomes of commitment (Meyer et al., 2002).

Many researchers have used the Organizational Commitment Questionnaire (OCQ) to measure employee commitment - notably affective commitment - whereas other researchers have used different measurement scales to assess all three components of commitment.

The OCQ was created, introduced and described by Porter et al. (1974) as an "attitudinal assessment" tool. Actually, Mowday et al. (1979) mentioned the necessity for an instrument that displays "acceptable psychometric properties" within the limits of attitude measurement in order to obtain more precise indicators of commitment (p.227).

The purpose of the OCQ was to identify 15 items that mostly illustrate the three factors stated in the definition of commitment (Mowday et al., 1979). Also, it was designed to assess the extent to which employees feel committed to the organization. Indeed, the questionnaire comprises items relevant to the employee's loyalty to the organization, his/her readiness to apply huge effort to achieve organizational goals, and his/her 
recognition of the organizational values (Porter et al., 1974). The response format to the statements representing the OCQ items used a 7-point Likert scale. Mowday et al. (1979) administered the OCQ to 2563 employees working in a diversity of jobs in 9 different companies.

On the other hand, measurement of behavioral commitment was addressed by Benkhoff (1997). She proposed a measurement scale based on the assumption that a more genuine picture of commitment is obtained from observing "what employees do" (i.e. behaviors) rather than "what they report about their opinions and feelings" (i.e. attitudes) (Benkhoff, 1997, p.706). The instrument developed was referred to as the Commitment Behaviour Scale (CBS) where commitment behavior is measured from two standpoints: in terms of staff self-evaluation and by staff members assessing their superior. The purpose is to prove whether the respective commitments of managers and employees are uniformly relevant (Benkhoff, 1997).

Moreover, citizenship behaviors have been deemed crucial because they "lubricate the social machinery" of the organization and offer the flexibility required to work through many "unforeseen contingencies" (Smith et al., 1983). In fact, OCB cannot be justified by the same motivational causes as those that entice people to join, stay, and perform within contractual and imposed "in-role" job instructions. It actually lays more resources on behalf of the organization and averts the need for costly formal procedures (Smith et al., 1983; Organ, 1988).

As previously mentioned, the relationship between organizational commitment and OCB has been explored by Meyer et al. (2002). Their research revealed that among the three components of commitment, affective commitment had the strongest positive correlation with OCB, followed by normative commitment. However, continuance commitment was found be unrelated or related negatively to that behavior. Also, it is worth mentioning that the OCB dimensions of altruism and conscientiousness were analyzed separately in the study and that the aforesaid correlations were somewhat similar for these two dimensions (Meyer et al., 2002).

As well, Rifai (2005) investigated the effect of affective commitment on OCB. Employees' affective organizational commitment is influenced by their perceptions of company support and fairness (Organ, 1988); indeed they will "reciprocate and exceed the minimum requirements of their job by helping others as well as the organization" (Rifai, 2005). Thus, 
from this "psychological" perspective, affective commitment is positively correlated to OCB.

Similarly, in a survey of 317 clerical workers, Morrison (1994) concluded that employees with a strong feeling of normative commitment consider themselves personally responsible for some forms of discretionary behaviors typically characterized as OCB.

On the other hand, job attitudes (i.e. job satisfaction and organizational commitment) have been proposed by Ackfeldt and Coote (2005) as direct antecedents of OCB. In fact, when employees are satisfied with their jobs and committed to their companies, they will reciprocate by engaging in citizenship behaviors. Thus, a positive correlation between job attitudes and OCB is expected (Ackfeldt and Coote, 2005; Organ and Konovsky, 1989; Organ and Ryan, 1995; Podsakoff et al., 2000; Van Dyne et al., 1994).

When relevant HR strategies and practices are effectively built and executed, then HR is expected to cause a significant influence on commitment. Likewise, 'high-commitment' HR practices aim to increase organizational effectiveness and efficiency and provide conditions "that encourage employees to identify with the goals of the organization and work hard to accomplish those goals" (Whitener, 2001, p.517). Highcommitment practices also refer to a system of HRM practices that intend to bring out employees' organizational commitment (Xiao and Björkman, 2006; Iverson and Zatzick, 2007). In fact, the basic element of a highcommitment system is the display of the employer's trust in the employees; executing these practices means the employer consistently expects that the employees "are trusted to reciprocate by their consummate Moreover, high-commitment HR practices include selective staffing, equitable compensation, inclusive training and development activities, performance appraisal, job design, information sharing, attitude assessment, and labor participation (Whitener, 2001; Gould-Williams, 2004). Also, Xiao and Björkman (2006) presented a more comprehensive list as a measurement construct of high-commitment systems. Table 4 illustrates the 15 items of that list.

It should be noted here that the term 'high commitment' is regularly employed in the UK in contrast to the term 'high performance' used in the US. Many scholars have stated that high-commitment HR systems affect employee behaviors and attitudes by promoting psychological ties between organization's and employee's goals (Huselid, 1995; Becker and 
Huselid, 1998; Gould-Williams, 2004). Actually, employers and executives applying high-commitment practices are basically attempting to nurture committed employees entrusted "to use their discretion to carry out job tasks in ways that are consistent with organizational goals" (GouldWilliams, 2004, p.64). Thus, high-commitment systems will develop an environment of exchange and reciprocity between a company and its workforce (Whitener, 2001, p.520; Knight-Turvey and Neal, 2003; GouldWilliams, 2004; Paul and Anantharaman, 2004; Iverson and Zatzick, 2007).

Some studies have explored the influence of HRM on employee citizenship behavior. Ackfeldt and Coote (2005) observed that leadership support, professional development, and empowerment are considerably associated to displaying OCB. As well, the outcomes of the study strongly support the positive relationship between job attitudes (i.e. commitment and job satisfaction) and citizenship behaviors, and these findings are consistent with other research results (Organ and Konovsky, 1989; Podsakoff et al., 2000; Williams and Anderson, 1991; Van Dyne et al., 1994). Indeed, as previously mentioned, feelings of job satisfaction and commitment to the organization - which are nurtured by specific HR practices - are key antecedents of OCB (Ackfeldt and Coote, 2005).

Additionally, Piercy et al. (2006) and Sun et al. (2007) found that high-performance HR practices promote employees' perceptions of a supportive work environment which in turn triggers discretionary behaviors commonly conceptualized in terms of OCB. In fact, and as discussed earlier in this chapter, the positive advantages of a flexible and friendly organizational environment drive employees to reciprocate with beneficial behaviors that best serve the company's interests (Sun et al., 2007).

\section{RESEARCH METHODOLOGY}

The primary research has been conducted in the Lebanese banking environment during the month of April-May 2015. The aim was to select leading banks across Lebanon. Six most representative banks have been selected and connected with their HR officials. A questionnaire on employee commitment and citizenship behavior was sent to each bank's HR officers who took care to administer it to an average of 10 employees. The instrument is divided into two constructs (commitment and OCB) which are then divided into scales representing dimensions of commitment 
or OCB. In fact, the Organizational Commitment Construct includes items associated with the four components/types of commitment and grouped according to these components, for instance Affective Commitment Scale, Continuance Commitment Scale, and so on. The construct and scales' items were derived from the most popular commitment measurement tools, mostly the OCQ, ACS, CCS, NCS, and CBS. As for the OCB Construct, it includes items associated with the five OCB dimensions and sorted according to these dimensions, for instance Compliance Scale, Courtesy Scale. The construct and scales' items were derived from the leading OCB measurement instruments, particularly the ones developed by Smith et al. (1983) and Ackfeldt and Coote (2005). The items had to be rated on a 5-point Likert scale, from 1 (Strongly Disagree) to 5 (Strongly Agree). Prior to administering the questionnaire, titles of the constructs and scales were removed and therefore not visible to the respondents. Completed questionnaires were either handed in directly to author or to HR manager/officer who delivered them to author in sealed envelopes, or they were sent back to author via email. A total of 60 questionnaires were collected.

In order to analyze the raw data, we used SPSS-17. This software is one of the most used programs for statistical analysis.

\section{EMPIRICAL RESULTS}

When considering the employee questionnaire results (Table 1 below), items related to OCB dimensions had a mean score of 3.8 (out of 5 ) which could be viewed as a fair hence not a low rating. Thus, the stated roles of HRM and firm management may have contributed to increasing extra-role efforts and fostering citizenship. The examples of citizenship behaviors mentioned by the interviewee are most closely associated to the OCB dimensions of helping behavior and civic virtue. Both of these dimensions also had the same acceptable mean score and certainly reflect the actual discretionary effort of employees. Though compliance dimension was not cited but scored high (4.3), it should not be surprising since this conscientious behavior is normally expected in such prominent organization with highly professional, competent and courteous workforce. 
Table 1: Fransa Bank Mean Scores for OCB Dimensions

\begin{tabular}{|c|c|c|}
\hline & Dimension & Mean Score \\
\hline \multirow{3}{*}{ OCB } & Helping & 3.8 \\
\hline & Compliance & 4.3 \\
\hline & $\gg>$ OCB Mean & 4.05 \\
\hline
\end{tabular}

When observing the questionnaire results and items pertaining to different types/components of commitment (Table 2 below), the mean score of these items is 3.5 which could be considered as a fair hence not a very low rating. The HRM initiatives may have played a role in increasing employee commitment from a previously very low level. Affective and behavioral commitment levels are around a score of 4 which is fairly high; these could be justified by the increased motivation that was stimulated by HRM intervention. However, it is expected to have an average normative commitment rating since this component is highly dependent on individual characteristics and perception of loyalty, thus the concepts of loyalty and "moral obligation" to stay with one organization are not commonly accepted or believed in. As for the quite average continuance commitment score, it simply suggests that this commitment component is weakly influenced by HRM involvement and that people are not holding on their jobs because of a socio-economic need (but rather a psychological attachment to the firm).

Table 2: Fransa Bank Mean Scores for Commitment Types

\begin{tabular}{|l|c|c|}
\hline \multirow{4}{*}{ Commitment } & Dimension & \multicolumn{1}{c|}{ Mean Score } \\
Affective Commitment & 4.1 \\
Continuance Commitment & 3.0 \\
Normative Commitment & 3.1 \\
Behavioral Commitment & 3.8 \\
\hline >>> Commitment Mean & 3.5 \\
\hline
\end{tabular}

When considering the employee questionnaire results (Table 3 below), 
items related to OCB dimensions had a mean score of 4.1 which is indeed a high rating. Thus, the stated roles of HRM (particularly employee champion) and the promoted values and culture may have contributed to cultivating citizenship. The highest scoring OCB dimension is compliance. These dimensions are very much associated to the mentioned values, cultures, and code of ethics. One should not neglect the role played by the employee relations department that encouraged employee contribution and recognized their efforts as stated, which makes employees reciprocate by positive behaviors such as civic virtue.

Table 3: Bank Audi Mean Scores for OCB Dimensions

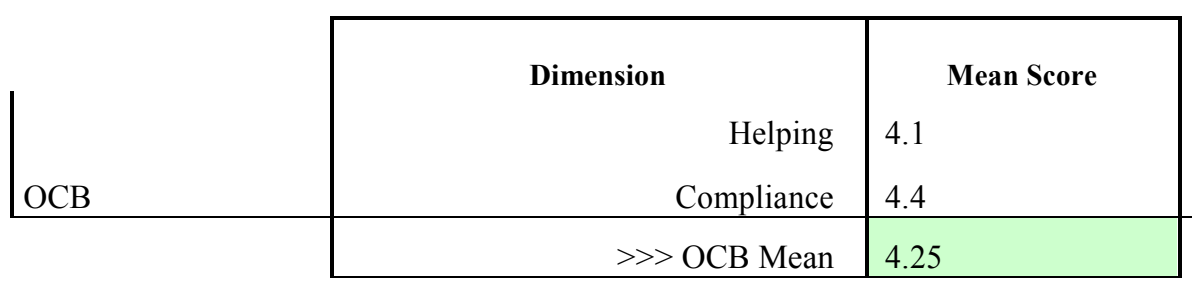

When observing the questionnaire results and items pertaining to different types/components of commitment (Table 4 below), their mean score is 3.6 which could be considered as a fair relative to the expected high level (by the interviewee). However, affective and then behavioral commitment have relatively much higher ratings than the other two components. Hence, the expectation of the interviewee may have been based on the affective component of commitment and on displaying commitment by behaviors (extra work etc.); hence the continuance and normative components' lower scores have cut the average as shown. The higher scores could be justified by the mentioned high motivation, HR and management support, effort recognition, and the other cited indicators consistent with the employee champion role (thus the employees reciprocating). Also, it is expected to have an average normative commitment rating because the concepts of loyalty and "moral obligation" to stay with one organization are not commonly accepted or believed in and are not said to be promoted within the organization. As for the very average continuance commitment score, it simply suggests that this commitment component is weakly influenced by HRM roles and that people are not keeping on their jobs because of financial and tangible 
benefits.

Table 4: Bank Audi Mean Scores for Commitment Types

\begin{tabular}{|l|l|l|}
\hline Commitment & \multicolumn{1}{|c|}{ Mean Score } \\
Affective Commitment & 4.2 \\
Continuance Commitment & 3.0 \\
Normative Commitment & 3.1 \\
Behavioral Commitment & 3.9 \\
>>> Commitment Mean & 3.6
\end{tabular}

When considering the employee questionnaire results (Table 5 below), items related to OCB dimensions had a mean score of 4.0 which is high as actually expected. Thus, the mentioned indicators - especially team spirit and young workforce - seem to have positively influenced OCB. The highest scoring OCB dimension is compliance. This dimension is very much linked to the high team spirit which endorses and largely relies on helping and courtesy. As for compliance, the rating should not be surprising since such behavior is very much expected in highly professional and competent environments.

Table 5: BLOM Bank Mean Scores for OCB Dimensions

\begin{tabular}{|l|r|l|}
\hline OCB & Mean Score \\
Helping & 4.2 \\
Compliance & 4.5 \\
\hline$>>$ OCB Mean & 4.0 \\
\hline
\end{tabular}

When examining the questionnaire results and items relating to different types/components of commitment (Table 6 below), their mean score is 3.9 which is high as actually expected by the interviewee. Affective component of commitment has an exceptionally high rating, followed by behavioral commitment. The fairly average normative 
commitment rating could be justified by the fact that concepts of loyalty and "moral obligation" to stay with one organization are not commonly accepted or believed in and are not said to be promoted within the organization. As for the moderately high continuance commitment score, this component is reasonably influenced by the high pay and benefits; thus employees perceive that other organizations may not match the overall financial and tangible benefits they have here, which explains their display of such level of continuance commitment.

Table 6: BLOM Bank Mean Scores for Commitment Types

\begin{tabular}{|l|r|l|}
\cline { 2 - 3 } \multicolumn{1}{c|}{ Dimension } & \multicolumn{1}{c|}{ Mean Score } \\
\hline Affective Commitment & 4.6 \\
Continuance Commitment & 3.7 \\
Normative Commitment & 3.3 \\
Behavioral Commitment & 3.9 \\
\hline >>> Commitment Mean & 3.9 \\
\hline
\end{tabular}

When considering the employee questionnaire results (Table 7 below), items related to OCB dimensions had a mean score of 4.0 which is high as actually expected. The cited indicators - especially the culture of fraternity and collectivism, and cooperation and team spirit - look to have positively influenced citizenship. All OCB dimensions could be viewed as having a high rating and their scores revolve around 4 . These dimensions are very much linked to the key role of employee champion and to the high team spirit which endorse and largely rely on helping and courtesy while collectivism largely promotes compliance.

Table 7: BLC Bank Mean Scores for OCB Dimensions

\begin{tabular}{|l|l|l|}
\cline { 2 - 3 } \multicolumn{1}{c|}{} & \multicolumn{1}{|c|}{ Mean Score } \\
\hline OCB & Helping & 4.2 \\
Compliance & 4.1 \\
\hline >> OCB Mean & 4.15 \\
\hline
\end{tabular}


When observing the questionnaire results and items pertaining to different types/components of commitment (Table 8 below), their mean score is 3.6 which are moderately high as actually expected by the interviewee. This mean rating may reflect the actual composition of the company's workforce, which is accordingly evenly split between the three staff levels with a little more experienced people. Affective commitment's high rating could be also associated to the workforce composition in addition to the mentioned transparency and communication of company image, and also the critical employee champion role. The fairly average normative commitment rating could be explained by the fact that the concepts of loyalty and "moral obligation" to stay with one organization are not commonly accepted or believed in. As for the fairly average continuance commitment score, it simply implies that this commitment component is weakly influenced by HRM roles and that people are not staying in their jobs because of financial benefits

Table 8: BLC Mean Scores for Commitment Types

\begin{tabular}{|l|r|l|}
\cline { 2 - 3 } & \multicolumn{1}{c|}{ Dimension } & Mean Score \\
\hline Commitment & Affective Commitment & 4.2 \\
Continuance Commitment & 3.1 \\
& Normative Commitment & 3.2 \\
Behavioral Commitment & 3.8 \\
\hline P> Commitment Mean & 3.6 \\
\hline
\end{tabular}

When considering the employee questionnaire results (Table 9 below), items related to OCB dimensions had a mean score of 3.9 which is acceptable as expected by the interviewee. The mentioned indicators especially satisfaction with training, increase in referrals, and the employee champion role - seem to have positively affected OCB, mainly courtesy, compliance, and helping behavior. These dimensions are very much linked to fairness (and treatment as partner/family member) which promotes courtesy while involvement and recognition largely supports helping and compliance. 
Table 9: SGBL Bank Mean Scores for OCB Dimensions

\begin{tabular}{|rr|l|}
\hline \multicolumn{2}{|r|}{ Dimension } & \multicolumn{2}{|c|}{ Mean Score } \\
& Helping & 3.8 \\
Compliance & 4.0 \\
\hline P> OCB Mean & 3.9 \\
\hline
\end{tabular}

When observing the questionnaire results and items relating to different types/components of commitment (Table 10 below), the mean score of these items is 3.2 which is an average score as expected by the interviewee. This rating actually reflects the composition of the company's workforce, which is increasingly being made up of young inexperienced individuals. Affective commitment's fair rating could be also linked to the workforce composition in addition to the mentioned flexibility and benefits. The average continuance commitment rating could be explained by stressing that this component is weakly influenced by HRM roles and that people are not staying in their jobs because of financial and tangible benefits. On the other hand, the somewhat low normative commitment rating could be explained by the fact that the concepts of loyalty and "moral obligation" to stay with one organization are not commonly accepted or believed in while adding that the workforce composition and the stated socio-cultural factors also negatively affect to a great extent the loyalty level and hence the normative commitment level.

Table 10: SGBL Bank Scores for Commitment Types

\begin{tabular}{|l|r|l|}
\cline { 2 - 3 } \multicolumn{4}{c|}{ Dimension } & \multicolumn{1}{|c|}{ Mean Score } \\
\hline Commitment & Affective Commitment & 3.5 \\
& Continuance Commitment & 3.2 \\
& Normative Commitment & 2.8 \\
& Behavioral Commitment & 3.3 \\
\hline & >>> Commitment Mean & 3.2 \\
\hline
\end{tabular}

When considering the employee questionnaire results (Table 11 
below), items related to OCB dimensions had a mean score of 4.1 which is indeed a high rating. Thus, the stated roles of HRM (particularly the role of employee champion) and the promoted values and culture could have contributed to nurturing citizenship. They are very much associated to the mentioned eagerness for teamwork, marketing for the firm, and the extra roles. One should not disregard the role played by HRM to daily support and assist employees, and that makes them reciprocate by such positive behavior.

Table 11: IBL Bank Mean Scores for OCB Dimensions

\begin{tabular}{|l|r|r|}
\cline { 2 - 3 } \multicolumn{1}{c|}{} & Dimension & Mean Score \\
\hline $\mathrm{OCB}$ & Helping & 4.1 \\
Compliance & 4.5 \\
\hline > & OCB Mean 4.3 \\
\hline
\end{tabular}

When observing the questionnaire results and items pertaining to different types/components of commitment (Table 12 below), the mean score of these items is 3.8 which is rather high as expected by the interviewee. Affective commitment has a particularly high rating, followed by both behavioral and normative commitment. Affective and normative components could be directly linked to all the factors stated by the HR manager, especially flexibility, high productivity, financial benefits, and empowerment. The behavioral component is mostly affected by both high productivity and the display of extra effort. The average continuance commitment rating could be justified as aforementioned: this component is weakly influenced by HRM roles and people are holding on their jobs because of socio-economic needs.

Table 12: IBL Bank Mean Scores for Commitment Types

\begin{tabular}{|l|l|l|}
\cline { 2 - 2 } \multicolumn{1}{c|}{} & Dimension & \multicolumn{1}{c|}{ Mean Score } \\
\hline Commitment & Affective Commitment 4.4 \\
& Continuance Commitment 3.0 \\
\hline Normative Commitment 3.9 \\
Behavioral Commitment 3.9 \\
\hline >>> Commitment Mean 3.8 \\
\hline
\end{tabular}


Table 13: Overall Organizational Commitment Results

\begin{tabular}{|l|r|l|l|l|r|l|}
\hline \multicolumn{1}{|c|}{ Dimension } & $\begin{array}{l}\text { Fransa } \\
\text { Bank }\end{array}$ & $\begin{array}{l}\text { Audi } \\
\text { Bank }\end{array}$ & $\begin{array}{l}\text { BLOM } \\
\text { Bank }\end{array}$ & $\begin{array}{l}\text { BLC } \\
\text { Bank }\end{array}$ & $\begin{array}{l}\text { SGBL } \\
\text { Bank }\end{array}$ & $\begin{array}{l}\text { IBL } \\
\text { Bank }\end{array}$ \\
\hline $\begin{array}{l}\text { Affective } \\
\text { commitment }\end{array}$ & 4.1 & 4.2 & 4.6 & 4.2 & 3.5 & 4.4 \\
\hline $\begin{array}{l}\text { Continuance } \\
\text { commitment }\end{array}$ & 3.0 & 3.0 & 3.7 & 3.1 & 3.2 & 3.0 \\
\hline $\begin{array}{l}\text { Normative } \\
\text { commitment }\end{array}$ & 3.1 & 3.1 & 3.3 & 3.2 & 2.8 & 3.9 \\
\hline $\begin{array}{l}\text { Behavioral } \\
\text { commitment }\end{array}$ & 3.8 & 3.9 & 3.9 & 3.8 & 3.3 & 3.9 \\
\hline $\begin{array}{l}\text { Commitment } \\
\text { Mean }\end{array}$ & 3.5 & 3.6 & 3.9 & 3.6 & 3.2 & 3.8 \\
\hline
\end{tabular}

The observed high levels of commitment (mainly affective, with a mean score of 4.2) are mostly justified by the factor "recognition of employee efforts". Thus, recognizing the employees' roles and efforts has most likely urged them to reciprocate with their own commitment to the organization (consistent with the literature). The following drivers of commitment are ranked from the most to the least cited: Recognition of employee roles and efforts; Availability of HR assistance; Fairness and equality; Relatively high salary and benefits; Learning and development; Employee years of experience; Leadership support.

Actually, these factors are all part of high-commitment HR practices which are deemed to improve employees' skills and motivation to work harder, and foster their psychological ties to the organization. Hence, in harmony with the literature, many high-commitment practices are being applied within the studied companies, certainly contributing to the observed level(s) of employees' commitment. As well, affective and then behavioral commitment have relatively much higher mean ratings than the other two components. Hence, employees' commitment is most commonly represented by their emotional attachment to their organization (as affective attitudinal commitment) and by displaying behaviors demonstrating sacrifice for its sake (such as extra work etc.). Also, contrary to results, it was expected as per the literature to have a similarly high normative commitment rating. However, at the social level, it appears that the concepts of loyalty and "moral obligation" to stay with one organization are not commonly accepted or believed in (anymore). As for the quite average continuance commitment score, it simply suggests that 
this commitment component is weakly influenced by HRM roles (compatible with literature findings) and that people are not just keeping on their jobs because of financial and tangible benefits. On the other hand, discussing the commitment driver stated as "high salary and benefits", we will observe the commitment levels of Blom Bank compared to those of BLC Bank.

Table 14: Overall OCB Results

\begin{tabular}{|l|r|r|r|r|r|r|r|l|}
\hline & Dimension & $\begin{array}{c}\text { FRANSA } \\
\text { Bank }\end{array}$ & $\begin{array}{c}\text { Bank } \\
\text { Audi }\end{array}$ & $\begin{array}{c}\text { Blom } \\
\text { Bank }\end{array}$ & $\begin{array}{c}\text { BLC } \\
\text { Bank }\end{array}$ & $\begin{array}{c}\text { SGBL } \\
\text { Bank }\end{array}$ & $\begin{array}{c}\text { IBL } \\
\text { BANK }\end{array}$ & $\begin{array}{c}\text { Overall } \\
\text { Mean }\end{array}$ \\
\hline \multirow{2}{*}{ OCB } & Helping & 3.8 & 4.1 & 4.2 & 4.2 & 3.8 & 4.14 .0 \\
\cline { 2 - 8 } & Compliance & 4.3 & 4.4 & 4.5 & 4.1 & 4.0 & 4.5 & 4.3 \\
\hline
\end{tabular}

The observed high levels of OCB (mainly compliance, with a mean score of 4.3) are mostly explained by the factor "fairness, respect, flexibility". Thus, treating employees fairly and with respect while providing a flexible work environment have most likely driven them to reciprocate with some discretionary and citizenship behaviors (consistent with the literature). The following drivers of OCB are ranked from the most to the least mentioned: Fairness, respect, flexibility; Support and follow-up by HR people; Treating them as "part of the family"; Explicit recognition of his/her efforts; High level of team spirit; Learning opportunities.

Essentially, these OCB drivers or antecedents are part of effective HR practices that promote an environment of exchange and reciprocity between employee and organization and strengthen the employeeemployer contract hence facilitating the display of such discretionary behaviors.

The highest scoring OCB dimensions are compliance, followed by helping. As per the literature, and concerning compliance, its high rating is very much expected in such highly professional, competent and motivating environments. Also, perception of fairness, support and assistance do affect the level of helping behavior.

On the other hand, with regards to the commitment-OCB relationship, and as shown in Figure 1, when using OCB as the dependent variable and organizational commitment as the independent variable, 
result of simple linear regression reveals a strong positive correlation with a coefficient of determination $\mathrm{R}^{2}$ around 0.7 (with the linear equation shown). Hence, $70 \%$ of the relation is explained by commitment-related factors while $30 \%$ remain unexplained. This portion may be attributed to other factors than commitment, most probably those mentioned by the companies' HR managers, for instance fair treatment, support, and recognition. A coefficient of determination $\mathrm{R}^{2}$ around 0.7 means a correlation coefficient of 0.83 . Thus, the high observed correlation is consistent with findings from the literature, where employees with strong emotional attachment to the organization are very much expected to engage in discretionary effort, psychological contract, and citizenship behaviors.

Figure 1: Commitment-OCB Correlation as per Questionnaire Results

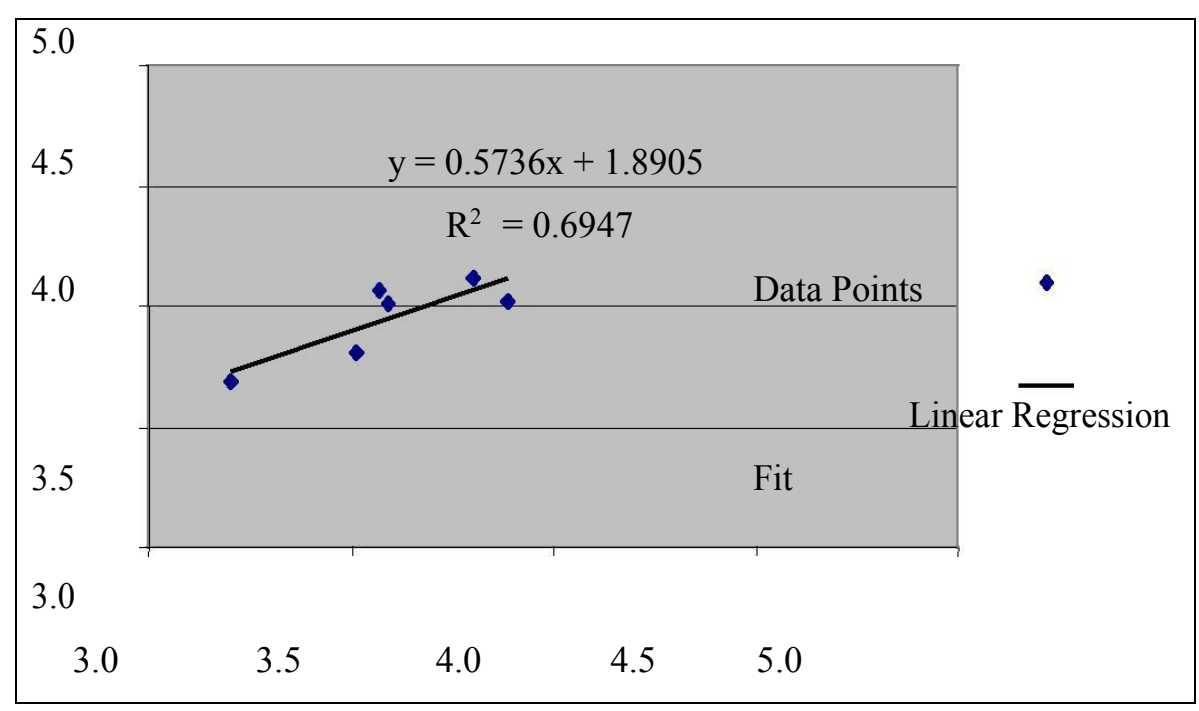

Table 15: Case Processing Summary

\begin{tabular}{|c|c|c|c|}
\hline & & $\mathbf{N}$ & $\%$ \\
\hline \multirow[t]{3}{*}{ Cases } & Valid & 59 & 98.3 \\
\hline & Excluded $^{\mathrm{a}}$ & 1 & 1.7 \\
\hline & Total & 60 & 100.0 \\
\hline
\end{tabular}

a. Listwise deletion based on all variables in the procedure. 
Table 16: Reliability Statistics

\begin{tabular}{|c|c|}
\hline Cronbach's Alpha & $\mathrm{N}$ of Items \\
\hline 0.745 & 18 \\
\hline
\end{tabular}

In this study, Cronbach's $\alpha$ is used to examine the internal consistency of each variable. If the Cronbach's $\alpha$ is below 0.70 , then the item is undesirable and the internal reliability does not meet the requirement. However, results with Cronbach's $\alpha$ above 0.70 are accepted and imply high level of internal consistency. The Cronbach's alpha test was implemented to represent the internal consistency of the scale and the sample that had been taken. The Cronbach alpha ranges from 0 to 1 . The more the result is close to 1 , and then it will show higher level of internal consistency. And the more the results move toward the 0 level, then a lower level of internal consistency will be seen. In the following table, the Cronbach alpha resulted with a 0.745 value near 1 . We can observe that the given Cronbach's values are above 0.70 which imply that the questionnaire being used is considered to be highly adequate due to the high level of internal consistency between both questions and scales.

Table 17: Emotionally attached v/s Loyalty: Correlations

\begin{tabular}{|c|c|c|c|}
\hline & & $\begin{array}{l}\text { I feel emotionally } \\
\text { attached to this } \\
\text { company. }\end{array}$ & $\begin{array}{c}\text { I believe that a } \\
\text { person must always } \\
\text { be loyal to his or her } \\
\text { organization. }\end{array}$ \\
\hline \multirow[t]{3}{*}{$\begin{array}{l}\text { I feel emotionally } \\
\text { attached to this company. }\end{array}$} & $\begin{array}{r}\text { Pearson } \\
\text { Correlation }\end{array}$ & 1 & $.719^{* *}$ \\
\hline & Sig. (2-tailed) & & .000 \\
\hline & $\mathrm{N}$ & 60 & 60 \\
\hline \multirow{3}{*}{$\begin{array}{l}\text { I believe that a person } \\
\text { must always be loyal to } \\
\text { his or her organization. }\end{array}$} & $\begin{array}{r}\text { Pearson } \\
\text { Correlation }\end{array}$ & $.719^{* *}$ & 1 \\
\hline & Sig. (2-tailed) & .000 & \\
\hline & $\mathrm{N}$ & 60 & 60 \\
\hline
\end{tabular}

**. Correlation is significant at the 0.01 level (2-tailed). 
Feeling Emotionally attached is correlated with Loyalty variable if the sig value is less than 0.05 it will show a start on the table of correlation the value of correlation is weak is its less than 0.5 and strong correlation if it's more than 0.5 .

Table 18: Moral obligation v/s Sacrifice for work: Correlations

\begin{tabular}{|c|c|c|}
\hline & $\begin{array}{c}\text { One of the major } \\
\text { reasons I continue to } \\
\text { work for this } \\
\text { organization is that I } \\
\text { believe that loyalty is } \\
\text { important and } \\
\text { therefore feel a sense } \\
\text { of moral obligation to } \\
\text { remain. }\end{array}$ & $\begin{array}{l}\text { My job is so } \\
\text { important to me } \\
\text { that I sacrifice } \\
\text { much for it. }\end{array}$ \\
\hline $\begin{array}{lr}\text { One of the major } & \begin{array}{r}\text { Pearson } \\
\text { reasons I continue to } \\
\text { Correlation } \\
\text { work for this } \\
\text { organization is that I } \\
\text { believe that loyalty is } \\
\text { important and } \\
\text { therefore feel a sense } \\
\text { of moral obligation to } \\
\text { remain. }\end{array} \\
\end{array}$ & 60 & $\begin{array}{r}.564^{* *} \\
.000 \\
60\end{array}$ \\
\hline $\begin{array}{lr}\text { My job is so important } & \text { Pearson } \\
\text { to me that I sacrifice } & \text { Correlation } \\
\text { much for it. } & \text { Sig. (2-tailed) } \\
& \mathrm{N}\end{array}$ & $\begin{array}{l}.564^{* *} \\
.000 \\
60\end{array}$ & 60 \\
\hline
\end{tabular}

**. Correlation is significant at the 0.01 level (2-tailed). 
Table 19: Work more than expected v/s help of employees: Correlations

\begin{tabular}{|lr|l|r|}
\hline & \multicolumn{1}{|c|}{$\begin{array}{c}\text { I work more than } \\
\text { typically expected } \\
\text { from somebody in my } \\
\text { position. }\end{array}$} & $\begin{array}{c}\text { I give my time to } \\
\text { help employees } \\
\text { with work-related } \\
\text { problems. }\end{array}$ \\
\hline $\begin{array}{l}\text { I work more than } \\
\text { typically expected } \\
\text { from somebody in my }\end{array}$ & $\begin{array}{r}\text { Pearson } \\
\text { Correlation }\end{array}$ & 1 & $.290^{*}$ \\
position. & Sig. (2-tailed) & & .024 \\
\hline $\begin{array}{l}\text { I give my time to help } \\
\text { employees with work- }\end{array}$ & $\begin{array}{r}\text { Pearson } \\
\text { Correlation }\end{array}$ & 60 & 60 \\
related problems. & Sig. (2-tailed) & .024 & 60 \\
\hline
\end{tabular}

*. Correlation is significant at the 0.05 level (2-tailed).

Working more than expected is correlated with time to help employees variable if the sig value is less than 0.05 it will show a start on the table of correlation the value of correlation is weak is its less than 0.5 and strong correlation if it's more than 0.5 .

Table 20: Emotionally attached v/s staying with organization: Correlations

\begin{tabular}{|c|c|c|c|}
\hline & & $\begin{array}{l}\text { I feel emotionally } \\
\text { attached to this } \\
\text { company. }\end{array}$ & $\begin{array}{c}\text { Right now, staying with } \\
\text { my organization is a } \\
\text { matter of necessity as } \\
\text { much as desire. }\end{array}$ \\
\hline $\begin{array}{l}\text { I feel emotionally } \\
\text { attached to this } \\
\text { company. }\end{array}$ & $\begin{array}{r}\text { Pearson } \\
\text { Correlation } \\
\text { Sig. (2-tailed) } \\
\mathrm{N}\end{array}$ & 60 & $\begin{array}{r}.750^{* *} \\
.000 \\
60\end{array}$ \\
\hline $\begin{array}{l}\text { Right now, staying with } \\
\text { my organization is a } \\
\text { matter of necessity as } \\
\text { much as desire. }\end{array}$ & $\begin{array}{r}\text { Pearson } \\
\text { Correlation } \\
\text { Sig. (2-tailed) } \\
\mathrm{N}\end{array}$ & $\begin{array}{l}.750^{* *} \\
.000 \\
60\end{array}$ & $\begin{array}{r}1 \\
60\end{array}$ \\
\hline
\end{tabular}

**. Correlation is significant at the 0.01 level (2-tailed).

Feeling Emotionally attached is correlated with staying with the organization variable if the sig value is less than 0.05 it will show a start on the table of correlation the value of correlation is weak is its less than 0.5 and strong correlation if it's more than 0.5 . 
Table 21: Emotionally attached v/s proud to tell others: Correlations

\begin{tabular}{|c|c|c|}
\hline & $\begin{array}{l}\text { I feel emotionally } \\
\text { attached to this } \\
\text { company. }\end{array}$ & $\begin{array}{l}\text { I am proud to tell } \\
\text { others that I am part } \\
\text { of this company. }\end{array}$ \\
\hline $\begin{array}{lr}\text { I feel emotionally } & \text { Pearson Correlation } \\
\text { attached to this } & \text { Sig. (2-tailed) } \\
\text { company. } & \mathrm{N}\end{array}$ & 60 & $\begin{array}{r}.568^{* *} \\
.000 \\
60\end{array}$ \\
\hline $\begin{array}{lr}\text { I am proud to tell } & \text { Pearson Correlation } \\
\text { others that I am } & \text { Sig. (2-tailed) } \\
\text { part of this } & \\
\text { company. } & \end{array}$ & $\begin{array}{l}.568^{* *} \\
.000 \\
60\end{array}$ & $\begin{array}{r}1 \\
60\end{array}$ \\
\hline
\end{tabular}

**. Correlation is significant at the 0.01 level (2-tailed).

Feeling Emotionally attached is correlated with proud to be part of the bank variable if the sig value is less than 0.05 it will show a start on the table of correlation the value of correlation is weak is its less than 0.5 and strong correlation if it's more than 0.5 .

\section{CONCLUSIONS AND RECOMMENDATION}

In general, it is evident that the role played by HRM and effective HR practices in promoting a committed environment and a culture of citizenship is vital. While the direct positive relationship between HR and organizational commitment has been proven in almost every studied company, on the combined aggregate of the Lebanese banking sector it could be said that the correlation is not completely verified. However, the HR-OCB relationship is much more coherent and noticeable especially when the HR role of employee champion emerges. Moreover, the commitment-OCB link is deemed to be strong. Finally, it appears that Lebanese banks are very promising examples of serious dynamic HRM initiatives that promote employees' support and recognize their efforts while trying to capitalize on their competences, commitment, and displayed citizenship behaviors.

As for my recommendations to the banks included in this study, I would first suggest enlarging/restructuring the HR department more horizontally (across functions) than vertically (across hierarchy) to meet organizational strategic objectives. Banks' HRM should also link their key HR practices with company targets and KPI's. As well, for the banks with more operationally reactive roles and low strategic involvement, they should gradually get implicated in strategy formulation, increase focus on vertical alignment, and involve line managers in HR strategy. 
Also, based on findings (especially regarding low levels of behavioral and affective commitment as well as low levels of compliance and helping), banks' HRM should increase their staff's participation and empowerment, promote a flexible and rewarding work environment, increase HR involvement and interest in employees' daily concerns, and foster knowledge sharing and learning culture. Finally, banks may conduct frequent employee satisfaction surveys in line with performance appraisals to monitor satisfaction with HR practices, job satisfaction, commitment, and turnover levels.

\section{REFERENCES}

Ackfeldt, Anna-Lena and Coote, Leonard V. "A Study of Organizational Citizenship Behaviors in a Retail Setting". Journal of Business Research 58 (2005): 151-159.

Allen, Natalie J. and Meyer, John P. "The Measurement and Antecedents of Affective, Continuance, and Normative Commitment to the Organization". Journal of Occupational Psychology 63, 1 (1990): 1-18.

Anthony, William P., Kacmar, Michele K., and Perrewe, Pamela L. Human Resource Management: A Strategic Approach. $4^{\text {th }}$ edition. South Western, Thomas Learning, 2002.

Armstrong, M. and Long, P. The Reality of Strategic HRM. Institute of Personnel and Development, 1994.

Armstrong, Michael and Baron, Angela. Strategic HRM: The Key to Improved Business Performance. CIPD Publishing, 2002.

Armstrong, Michael. Handbook of Human Resource Management Practice. $10^{\text {th }}$ Edition. Kogan Page, 2006.

Becker, Brian E. and Huselid, Mark A. "High Performance Work Systems and Firm Performance: A Synthesis of Research and Managerial Implications". Research in Personnel and Human Resources Management 16 (1998): 53101.

Becker, Brian E. and Huselid, Mark A. "Strategic Human Resources Management: Where Do We Go From Here?" Journal of Management 32, 6 (2006): 898-925.

Becker, Brian E., Huselid, Mark A., Pickus, Peter, and Spratt, Michael. "HR as a Source of Shareholder Value: Research and Recommendations". Human Resource Management 36, 1 (1997): 39-47.

Benkhoff, Birgit. "Ignoring Commitment Is Costly: New Approaches Establish the Missing Link Between Commitment and Performance". Human Relations 50, 6 (1997): 701-726.

Bergeron, Diane M. "The Potential Paradox of Organizational Citizenship Behavior: Good Citizens at What Cost?" Academy of Management Review 32, 4 (2007): 1078-1095. 
Buck, Jeffrey M. and Watson, John L. "Retaining Staff Employees: The Relationship Between Human Resources Management Strategies and Organizational Commitment". Innovative Higher Education 26, 3 (2002): 175-193.

Buyens, D. and De Vos, A. "Perceptions of the Value of the HR Function." Human Resource Management Journal 11, 3 (2001): 70-89.

Collins, Christopher J. and Clark, Kevin D. (2000) . "Strategic Human Resource Practices, Top Management Team Social Networks, and Firm Performance: The Role of Human Resource Practices in Creating Organizational Competitive Advantage". Academy of Management Journal 46, 6 (2003): 740-751.

Cook, J. and Wall, T. "New Work Attitude Measures of Trust, Organizational Commitment and Personal Need Non-Fulfilment". Journal of Occupational Psychology 53 (1980): 39-52.

Currivan, Douglas B. "The Causal Order of Job Satisfaction and Organizational Commitment in Models of Employee Turnover". Human Resource Management Review 9, 4 (1999): 495-524.

Decenzo, D. and Robbins, S. Human Resource Management, $7^{\text {th }}$ Edition. John Wiley \& Sons, Inc., 2002.

Feather, N. T. and Rauter, Katrin A. "Organizational Citizenship Behaviours In Relation to Job Status, Job Insecurity, Organizational Commitment and Identification, Job Satisfaction and Work Values". Journal of Occupational and Organizational Psychology 77 (2004): 81-94.

Fiorito, Jack, Bozeman, Dennis P., Young, Angela, and Meurs, James A. "Organizational Commitment, Human Resource Practices, and Organizational Characteristics". Journal of Managerial Issues 19, 2 (2007): 186-207.

Gaertner, Stefan. "Structural Determinants of Job Satisfaction and Organizational Commitment in Turnover Models". Human Resource Management Review 9, 4 (1999): 479-493.

Gilbreath, B. and Montesino, M. U. "Expanding the HRD Role: Improving Employee Well-Being and Organizational Performance". Human Resource Development International 9, 4 (2006): 563-571.

Gould-Williams, Julian. "The Effects of 'High Commitment' HRM Practices on Employee Attitude: The Views of Public Sector Workers". Public Administration 82, 1 (2004): 63-81.

Guest, D., Michie, J., Conway, N., and Sheehan, M. "Human Resource Management and Corporate Performance in the UK". British Journal of Industrial Relations, 41, 2 (2003): 291-314.

Huselid, M. A. "The Impact of Human Resource Management Practices on Turnover, Productivity, and Corporate Financial Performance". Academy of 
Management Journal 38, 3 (1995): 635-672.

IRS. "Survey of HR Roles and Responsibilities". Employment Review 795 (2004): 9-15.

Iverson, Roderick D. and Zatzick, Christopher D. "High-Commitment Work Practices and Downsizing Harshness in Australian Workplaces". Industrial Relations 46, 3 (2007): 456-480.

Khilji, Shaista. E. and Wang, Xiaoyun. "New Evidence in an Old Debate: Investigating the Relationship between HR Satisfaction and Turnover". International Business Review 16, 3 (2007): 377-395.

Knight-Turvey, N. and Neal, A. “'High Commitment' Human Resource Practices, Affective Organisational Commitment, and Employee Level Outcomes: The Role of Perceived Organisational Support". Australian Journal of Psychology 55 (2003): 134-134.

Kuvaas, Bård. "An Exploration of How the Employee-Organization Relationship Affects the Linkage Between Perception of Developmental Human Resource Practices and Employee Outcomes". Journal of Management Studies 45, 1 (2008): 1-25.

Mellor, Steven, Mathieu, John E, Barnes-Farrell, Janet L., and Rogelberg, Steven G. "Employees' Nonwork Obligations and Organizational Commitments: A New Way to Look at the Relationships". Human Resource Management 40, 2 (2001): 171-184

Meyer, John P. and Allen, N. J. "A Three-component Conceptualization of Organizational Commitment". Human Resource Management Review 1, 1 (1991): 61-89.

Meyer, John P. and Allen, N. J. Commitment in the Workplace: Theory, Research, and Application. Sage Publications, 1997.

Meyer, John P., Stanley, David J., Herscovitch, Lynne, and Topolnytsky, Laryssa. "Affective, Continuance, and Normative Commitment to the Organization: A Meta-analysis of Antecedents, Correlates, and Consequences". Journal of Vocational Behavior 61 (2002): 20-52.

Mintzberg, H. "Patterns in Strategy Formation". Management Sciences 24 (1978): 934-948.

Mondy, Wayne R. and Noe, Robert M. Human Resource Management. $9^{\text {th }}$ Edition. International Edition. Prentice Hall, 2005.

Moorman, Robert H. "Relationship Between Organizational Justice and Organizational Citizenship Behaviors: Do Fairness Perceptions Influence Employee Citizenship?" Journal of Applied Psychology 76, 6 (1991): 845855.

Morrison, Elizabeth Wolfe. "Role Definitions and Organizational Citizenship Behavior: The Importance of the Employee's Perspective". Academy of Management Journal 37, 6 (1994): 1543-1567. 
Mowday, R. T., Steers, R. M., and Porter, L. W. "The Measurement of Organizational Commitment”. Journal of Vocational Behavior 14 (1979): 224-247.

Moynihan, Donald P. and Pandey, Sanjay K. "The Ties that Bind: Social Networks, Person-Organization Value Fit, and Turnover Intention". Journal of Public Administration Research and Theory 18, 2 (2008): 205-227.

Organ D. W. Organizational Citizenship Behavior: The Good Soldier Syndrome. Lexington Books, 1988.

Organ, D. W. and Konovsky, M. "Cognitive Versus Affective Determinants of Organizational Citizenship Behavior". Journal of Applied Psychology 74, 1 (1989): 157-164.

Organ, D. W. and Ryan, K. "A Meta-analytic Review of Attitudinal and Dispositional Predictors of Organizational Citizenship Behavior". Personnel Psychology 48, 4 (1995): 775-802.

Paul, A. K. and Anantharaman, R. N. "Impact of People Management Practices on Organizational Performance: Analysis of a Causal Model". The International Journal of Human Resource Management 14, 7 (2003): 12461266.

Paul, A. K. and Anantharaman, R. N. "Influence of HRM Practices on Organizational Commitment: A Study Among Software Professionals in India”. Human Resource Development Quarterly 15, 1 (2004): 77-88.

Piercy, Nigel F., Cravens, David W., Lane, Nikala, and Vorhies, Douglas W. "Driving Organizational Citizenship Behaviors and Salesperson In-Role Behavior Performance: The Role of Management Control and Perceived Organizational Support". Journal of the Academy of Marketing Science 34, 2 (2006): 244-262.

Podsakoff, P. M. and MacKenzie, S. B. "Organizational Citizenship Behaviors and Sales Unit Effectiveness". Journal of Marketing Research 31, 3 (1994): 351-363.

Podsakoff, P. M., Ahearne, M., and MacKenzie, S. B. "Organizational Citizenship Behavior and the Quality of Work Group Performance". Journal of Applied Psychology 82 (1997): 262-270.

Podsakoff, P. M., MacKenzie, S. B., Paine, J. B., and Bachrach, D. G. "Organizational Citizenship Behaviors: A Critical Review of the Theoretical and Empirical Literature and Suggestions for Future Research". Journal of Management 26, 3 (2000): 513-563.

Porter, L. W., Steers, R. M., Mowday, R. T., and Boulian, P. V. "Organizational Commitment, Job Satisfaction, and Turnover Among Psychiatric Technicians". Journal of Applied Psychology 59, 5 (1974): 603-609.

Rifai, Harif Amali. "A Test of the Relationships Among Perceptions of Justice, Job Satisfaction, Affective Commitment and Organizational Citizenship 
Behavior”. Gadjah Mada International Journal of Business 7, 2 (2005): 131154.

Ritzer, G. and Trice, H. M. "An Empirical Study of Howard Becker's Side-bet Theory”. Social Forces 47 (1969): 475-479.

Robinson, Sandra L. and Morrison, Elizabeth Wolfe. "Psychological Contracts and OCB: The Effect of Unfulfilled Obligations on Civic Virtue Behavior". Journal of Organizational Behavior 16, 3 (1995): 289-298.

Rogg, K. L., Schmidt, D. B., Shull, C., and Schmitt, N. "Human Resource Practices, Organizational Climate, and Customer Satisfaction". Journal of Management 27 (2001): 431-449.

Salancik, G. R. "Commitment and the Control of Organizational Behavior and Belief". In Staw, B. M. and Salancik, G. R. (Eds), New Directions in Organizational Behavior. St. Clair Press, 1977.

Schwepker Jr., Charles H. "Ethical Climate's Relationship to Job Satisfaction, Organizational Commitment, and Turnover Intention in the Salesforce". Journal of Business Research 54 (2001): 39- 52.

Selouan, Claudine. Head of Recruitment and Selection Department, Human Resources, Bank Audi s.a.l. Interviewed by author, 14 May 2008, Beirut, Lebanon.

Sheehan, Cathy. "A Model for HRM Strategic Integration." Personnel Review 34, 2 (2005): 192-209.

Smith, C. A., Organ, D. W., and Near, J. P. "Organizational Citizenship Behavior: Its Nature and Antecedents". Journal of Applied Psychology 68, 4 (1983): 653-663.

Sun, Li-Yun, Aryee, Samuel, and Law, Kenneth S. "High-Performance Human Resource Practices, Citizenship Behavior, and Organizational Performance: A Relational Perspective". Academy of Management Journal 50, 3 (2007): 558-577.

Swailes, Stephen. "Organizational Commitment: A Critique of the Construct and Measures". International Journal of Management Reviews 4, 2 (2002): 155178.

Ulrich, D. Human Resource Champions: The Next Agenda for Adding Value and Delivering Results. Harvard Business School Press, Boston, Massachusetts, 1997.

Van Dyne, Linn, Graham, Jill W., and Dienesch, Richard M. "Organizational Citizenship Behavior: Construct Redefinition, Measurement, and Validation". Academy of Management Journal 37, 4 (1994): 765-802.

Van Veldhoven, M. "Financial Performance and the Long-Term Link with HR Practices, Work Climate and Job Stress". Human Resource Management Journal 15, 4 (2005): 30-53.

Whitener, Ellen M. "Do "high commitment" human resource practices affect 
employee commitment? A cross-level analysis using hierarchical linear modeling”, Journal of Management 27 (2001): 515-535.

Wiener, Y. and Vardi, Y. "Relationships Between Job, Organization, and Career Commitments and Work Outcomes: An Integrative Approach". Organizational Behavior and Human Performance 26, 1 (1980): 81-96.

Williams, L. J. and Anderson, S. E. "Job Satisfaction and Organizational Commitment as Predictors of Organizational Citizenship and In-Role Behaviors". Journal of Management 17 (1991): 601-617.

Wittig-Berman, U. and Lang, D. “Organizational Commitment and Its Outcomes: Differing Effects of Value Commitment and Continuance Commitment on Stress Reactions, Alienation and Organization-Serving Behaviors". Work and Stress 4 (1990): 167-177.

Wright, P. M., Gardner, T. M., and Moynihan, L. M. "The Impact of HR Practices on the Performance of Business Units". Human Resource Management Journal 13, 3 (2003): 21-36.

Xiao, Zhixing and Björkman, Ingmar. "High Commitment Work Systems in Chinese Organizations: A Preliminary Measure". Management and Organization Review 2, 3 (2006): 403-422. 